\title{
APPLYING FREEDMAN $v$. MARYLAND TO CAMPUS SPEAKER BANS
}

To a sponsoring student group, an on-campus speech by someone not formally affiliated with the academic community offers an opportunity to hear opinions often not presented in the classroom. But to a university administrator, an outside speaker is often a potentially disruptive influence-likely to cause strife both within the academic community and between that community and the outside world. In the face of student requests or demands to present an outside speaker, the administrator may desire to regulate access to the school platform. From this desire springs the institutional control: the speaker ban. ${ }^{1}$

Because advance permission to speak is required, the speaker ban is an administrative prior restraint on the first amendment rights of both audience and speaker. ${ }^{2}$ Although presumptively invalid, ${ }^{3}$ prior restraints are not per se unconstitutional. ${ }^{4}$ Thus courts in speaker ban cases have focused on the particular prior restraint to determine whether it is administered to "suppress only that speech which presents a 'clear and present danger' of resulting in serious substantive evil which a university has a right to prevent." 5 But although the courts have been active in articulating narrow standards for administrative decisionmaking ${ }^{6}$ and in liberalizing

1 Under the speaker ban, university and college administrators determine who will be permitted to speak on campus. When exercised by administrators of statesupported institutions, this authority is subject to constitutional restrictions because first amendment rights of free speech, held applicable to the states as part of fourteenth amendment due process, see Hughes v. Superior Court, 339 U.S. 460 (1950); Whitney v. California, 274 U.S. 357 (1927), have also been held applicable to public school boards as agencies of the state. West Virginia State Bd. of Educ. v. Barnette, 319 U.S. 624 (1943). See also Developments in the Law-Academic Freedom, 81 HARv. L. REv. 1045, 1056-64 (1968). Although a school might constitutionally ban all outside speakers from campus, it cannot ban only some on a discriminatory basis. See Stacy v. Williams, 306 F. Supp. 963, 971 (N.D. Miss. 1969) (3-judge court); Dickson v. Sitterson, 280 F. Supp. 486, 497 (M.D.N.C. 1968) ; Danskin v. San Diego Unified School Dist., 28 Cal. 2d 536, 545-46, 171 P.2d 885, 891 (1946). This Comment focuses upon a limited rather than a total speaker ban because virtually all state-supported universities and colleges permit at least some outside speakers to appear on campus. Comment, Mississippi's Campus Speaker Ban: Constitutional Considerations and the Academic Freedom of Students, 38 Miss. L.J. 488, 493 (1967).

2 The prior restraint doctrine dates back at least to the eighteenth century. See $4 \mathrm{~W}$. Blackstone, Commentaries $* 151-52$. The first case in which the doctrine was given constitutional recognition by the Supreme Court, however, was Near v. Minnesota, 283 U.S. 697 (1931).

3 Freedman v. Maryland, 380 U.S. 51, 57 (1965) ; Bantam Books, Inc. v. Stllivan, 372 U.S. 58, 70 (1963).

4 Times Film Corp. v. City of Chicago, 365 U.S. 43 (1961); see Freedman v. Maryland, 380 U.S. 51, 53-54 (1965); Near v. Minnesota, 283 U.S. 697, 716 (1931).

5 Stacy v. Williams, 306 F. Supp. 963, 971 (N.D. Miss. 1969) (3-judge court); cf. Speiser v. Randa11, 357 U.S. 513, 520-21 (1958).

6 See, e.g., Stacy v. Williams, 306 F. Supp. 963, 971 (N.D. Miss. 1969) (3-judge court) (clear and present danger). In Pickings v. Bruce, 430 F.2d 595 (8th Cir. 1970), the court indicated that "the administrators could enforce a ban, if they could reasonably forecast that [the proposed speaker's] presence on campus would substantially interfere with the work of school, the rights of students and the maintenance of appropriate discipline." Id. at 599 (relying on Tinker v. Des Moines Community School Dist., 393 Ư.S. 503 (1969)). 
standing requirements, ${ }^{7}$ even the most explicit and far-reaching decision fails to insure that a proposed speaker will be banned only after a judicial determination that his speech presents a clear and present danger to the institution's orderly operation. This Comment contends that only such a requirement can adequately protect freedom of speech.

\section{Judicial Rulemaking for the Campus}

In Stacy $v$. Williams, ${ }^{8}$ students and faculty in the Mississippi state university system attacked the constitutionality of regulations for offcampus speakers adopted by the Board of Trustees of the Institutions of Higher Learning of the State of Mississippi and applied to all institutions under its supervision. After a finding that the Board's regulations were unconstitutional, and after an unsuccessful attempt by the Board to conform its regulations to constitutional requirements, the district court granted relief in the form of its own set of regulations "applicable to all institutions of higher learning within the state of Mississippi." o

In formulating its regulations, the court sought to establish an integrated system which would protect both the school's legitimate concern for peaceful and orderly operation and the plaintiffs' constitutional rights to free speech. ${ }^{10}$ Under these regulations, proposed invitations may be requested only by recognized student or faculty groups and may not be extended without the "prior written concurrence" of the university head or his designee. ${ }^{11}$ Any request must be made at least ten days before the proposed date of the speech and must contain "the name of the sponsoring organization, the proposed date, time and location of the meeting, the expected size of the audience and topic of speech." 12 The head of the institution is then given four days to rule on the request, or the "submission shall be deemed granted." 13

The regulations provide explicit standards for administrative decisionmaking. Thus the head of the institution may deny the request only if he or an authorized designee

7 Standing to assert a denial of first amendment rights has been consistently granted to the sponsoring group. See Brooks v. Auburn Univ., 412 F.2d 1171, 1172 (5th Cir. 1969) (first amendment right to hear) ; Smith v. University of Tennessee, 300 F. Supp. 777, 780 (E.D. Tenn. 1969) (first amendment protection of speech extends to audience); Snyder v. Board of Trustees, 286 F. Supp. 927, 932 (N.D. IIl. 1968) (first amendment right to assemble to hear chosen speaker). See generally Comment, Do College Students Have a Constitutionally Protected Right to Hear Outside Speakers?, 41 Miss. L.J. 135 (1969).

8306 F. Supp. 963 (N.D. Miss. 1969) (3-judge court).

9 Id. at 979.

10 The court deemed it a proper exercise of its equity powers to provide the parties with relief in this fashion. The Board of Trustees could repeal the regulations, because it was not required to formulate any rules, or could adopt other regulations consistent with the court's opinion. Id. at 978-79.

11 Id. at 979.

12 Id.

${ }^{13} I d$. 
determines, after proper inquiry, that the proposed speech will constitute a clear and present danger to the institution's orderly operation by the speaker's advocacy ${ }^{14}$ of such actions as :

1. The violent overthrow of the government of the United States . . or

2. The willful damage or destruction, or seizure and subversion, of the institution's buildings or other property; or

3. The forcible disruption or impairment of, or interference with, the institution's regularly scheduled classes or other educational functions; or

4. The physical harm, coercion, intimidation, or other invasion of lawful rights, of the institution's officials, faculty members or students; or

5. Other campus disorder of a violent nature. ${ }^{15}$

The standards by which the existence of a clear and present danger is determined permit the administrator to take into account the speaker's past conduct. ${ }^{16}$

If the request is denied, the sponsoring group has a right of appeal for a de novo hearing within two days by a campus review committee "composed of three faculty members and two students." 17 If the request is denied again, the sponsoring group may obtain judicial review, and the court is to reverse or affirm following a hearing "conducted as soon as practicable." 18

These regulations clearly erect an elaborate procedural structure for administering the speaker ban. Explicit standards restrict the administrator's discretion, and time limits assure that requests are not denied by delay. Yet Molpus v. Fortune ${ }^{19}$ demonstrates that these procedural safeguards leave essentially untouched the potential for abuse inherent in the speaker ban. Subject only to the check of judicial review initiated by the sponsoring group, the school administrator,

14 Advocacy is defined as preparing the group for imminent action, as distinguished from mere abstract espousal of a doctrine. Id. at 979 n.1.

$15 \mathrm{Id}$. at 979.

16 In determining the existence of a clear and present danger, the head of the institution, or his authorized designee, may consider all relevant factors, including whether such speaker has, within the past five years, incited violence resulting in the destruction of property at any state educational institution or has willfully caused the forcible disruption of regularly scheduled classes or other educational functions at any such institution.

Id. at $979-80$.

$17 \mathrm{Id}$. at 980 .

$18 \mathrm{Id}$.

19311 F. Supp. 240 (N.D. Miss.), aff'd, 432 F.2d 916 (5th Cir. 1970). For another case decided under the rules, see Stacy v. Williams, 312 F. Supp. 742 (N.D. Miss. 1970), in which the court invalidated the Board's denial of a request approved earlier by the university president and the campus review committee. 
although formally complying with the Stacy rules, can still effectively frustrate the exercise of first amendment rights.

On March 4, 1970, the University of Mississippi Young Democrats (UMYD) presented to Chancellor Fortune a request for permission to invite Tyrone Gettis to speak on March 18. Mr. Gettis was president of the student body at Mississippi Valley State College (MVSC) and the leader of recent demonstrations and a boycott which had closed that school. ${ }^{20}$ Interested in receiving a firsthand report of events given extensive coverage by the mass media, UMYD members wanted a student's view of the "Crisis at MVSC." 21

That same day, Chancellor Fortune notified UMYD that he would not approve the request. From newspaper clippings and conversations with college officials, Chancellor Fortune concluded that "his appearance, as a guest speaker on the campus, would constitute a clear and present danger to the institution's orderly operations, because of the likelihood that Mr. Gettis would advocate [the evils listed in the Stacy regulations] . . . ."22

UMYD then requested review by the campus review committee which, without making a record of the hearing or of its findings, voted four to one against granting permission. On March 9, members of UMYD brought a class action in the district court seeking an injunction directing the university to approve the request. ${ }^{23}$

The district court decided first that review of the committee's action would be impossible because of the unavailability of a record, and that a de novo hearing should be granted. After considering the evidence anew, the court held that the university had failed to meet its burden of showing by clear and convincing proof that the speech would constitute a clear and present danger to its orderly operation. ${ }^{24}$ The court found that "Mr. Gettis proposes to limit his speech to a discussion of the crisis at Mississippi Valley State College, as viewed by him as a student leader." ${ }^{25}$ Should he extend his remarks and

20 UMYD also proposed to invite the president of MVSC. 432 F.2d at 919.

21 This was the title of the proposed speech. Id.

22311 F. Supp. at 242. The chancellor's reasons for denying permission to speak were a verbatim listing of the Stacy court's justifications. But as the evidence later showed, "one of the attorneys for UMYD visited Mr. Gettis . . . and talked with him about the proposed speech," and "Mr. Gettis assured [him] that his speech would be devoted entirely to the assigned subject." Id. at 248. At the district court hearing the evidence consisted of each side's witnesses' estimation whether Mr. Gettis would present a clear and present danger. Id. Chancellor Fortune was one of the witnesses. The court found that he "was not fearful that Mr. Gettis' appearance on the campus would result in disorders such as occurred at [MVSC]." Rather, "Chancellor Fortune's main concern was to avoid a disturbance of any nature." Id.

${ }^{23} I d$. at 243. They also requested "an injunction to restrain the defendants from further interference with the rights of students at the University to assemble peaceably and to hear speeches made by speakers of their choice," and asked that the court "establish procedural guidelines for the operation of the Campus Review Committee." Id. The district court refused to grant these two requests because the Stacy court had retained jurisdiction of the matter. Id. at 244 .

$24 I d$. at $246-49$.

$25 I d$. at 249. 
advocate destruction of university property or similar violence, "there does not appear to be a reasonable probability that [those evils] would happen." 26

The university appealed. Despite their successful reliance on the Stacy rules in the district court, the plaintiffs on cross-appeal sought to have the court of appeals review the rules and hold them invalid on the ground that the clear and present danger standards inadequately protected first amendment rights. ${ }^{27}$ Plaintiffs also renewed their requests for an injunction that would require the university to institute court action in order to ban a speaker and for the establishment of "standards of administrative due process to deal with future hearings before the Campus Review Committee." 28 The Fifth Circuit affirmed, but refused to examine the validity of the Stacy rules, finding that the plaintiffs were entitled to relief on the ground that the university had failed to meet even the clear and present danger standards of those rules. ${ }^{29}$

Although not remarkable for its holding or legal analysis, ${ }^{30}$ Molpus does highlight the dangers inherent in relying upon administrative determinations of the character of a proposed speech. As the district court noted, "[we are] positive that [Chancellor Fortune and the campus review committee] acted in good faith and in accord with that which they thought would be for the best interests of the University." They were, however, "overly cautious in their actions." 31

\section{Procedural Requirements for Restricting ACCESS to The CAMPUS}

In recent years, "courts have begun to construct a body of procedural law which defines the manner in which they and other bodies must evaluate and resolve first amendment claims . . . ." 32 Allowing a school administrator to ban a proposed speaker without first securing a judicial determination of the character of the speech fails to satisfy procedural standards the Supreme Court has set forth for the regulation of other kinds of expression.

$26 I d$.

$27432 \mathrm{~F} .2 \mathrm{~d}$ at 920 . The rules' clear and present danger standards are quoted at note 16 supra.

28432 F.2d at 920 .

$29 \mathrm{Id}$. at 921 . The court added that it would review Stacy only when an action was brought "seeking appropriate relief which challenges Stacy," and suggested that because the Stacy court had retained jurisdiction for enforcement of the order, the "ideal place" to begin such an action would be in the Stacy court itself. Id.

30 See Pickings v. Bruce, 430 F.2d 595, 598-99 (8th Cir. 1970) ("We have been unable to find a single case decided in the 1960's in which a speaker ban has been upheld by a federal court.") (footnote omitted) ; Brooks v. Auburn Univ., 412 F.2d 1171 (5th Cir. 1969); Wright, The Constitution on the Campus, 22 Vand. L. REv. 1027, 1050 (1969) ("[I]t is hardly surprising that I cannot find a single case decided on its merits in this decade in which a speaker ban has been upheld by a court.").

31311 F. Supp. at 249.

32 Monaghan, First Amendment "Due Process," 83 Harv. L. Rev. 518 (1970). 
In Freedman $v$. Maryland, ${ }^{33}$ the Court reversed the conviction of a movie exhibitor who had shown a film without first submitting it to the state board of censors. The statute requiring submission imposed upon the exhibitor the burden of securing judicial review of a board decision banning a film and of proving that the film was protected expression, and placed no time limits upon administrative or judicial action. $^{34}$ In holding this procedure unconstitutional, the Court ruled that a system of censorship could not be administered so as to give an effect of finality to the censor's determinations.

[B] ecause only a judicial determination in an adversary proceeding ensures the necessary sensitivity to freedom of expression, only a procedure requiring a judicial determination suffices to impose a valid final restraint. ${ }^{35}$

To effectuate this principle, the Court required (1) that after submitting a film the exhibitor be "assured . . . that the censor will, within a specified brief period, either issue a license or go to court to restrain showing the film"; (2) that any restraint prior to a final judicial determination be "limited to preservation of the status quo for the shortest fixed period compatible with sound judicial resolution"; and (3) that prompt, final judicial decision be assured. ${ }^{36}$ These requirements result from a recognition that a system of prior restraint may easily abridge constitutional freedoms. Because permission must be sought in every instance, the censor scrutinizes clearly protected as well as borderline communication; ${ }^{37}$ and censorship may become the rule, freedom of expression the exception.

Freedman's basic requirement of a prompt, final judicial determination of the character of the proposed communication is even more critical for the protection of first amendment rights in cases involving university speakers than in those involving movie distributors. ${ }^{38}$ First, restraint may cause irreparable harm to the political speaker and his audience, but rarely more than delay and financial loss (perhaps only temporary) to a distributor. As Mr. Justice Harlan remarked in a decision holding unconstitutional a city ordinance requiring parade licenses:

33380 U.S. 51 (1965).

34 Id. at $59-60$.

35 Id. at 58. The Court also ruled that the censor must assume the burden of proving that the film was constitutionally unprotected. Id.

$36 I d$. at 59.

37 See Emerson, The Doctrine of Prior Restraint, 20 LAw \& ConTeNr. Prob. $648,656-57$ (1955). 38

Nothing in the rationale of Freedman and its predecessors suggests that their principles are confined to the obscenity area. In fact, when the subject matter of speech is political in character rather than bordering on the obscene, the need for a disinterested judicial judgment is even greater.

Monaghan, supra note 32 , at 524 . 
Though a movie exhibitor might suffer some financial loss if he were obliged to wait for a year or two while the administrative and judicial mills ground out a result, it is nevertheless quite likely that the public would ultimately see the film. In contrast, timing is of the essence in politics. It is almost impossible to predict the political future; and when an event occurs, it is often necessary to have one's voice heard promptly, if it is to be considered at all. ${ }^{39}$

Similarly, the Supreme Court has noted:

"It is vital to the operation of democratic government that the citizens have facts and ideas on important issues before them. A delay of even a day or two may be of crucial importance in some instances. On the other hand, the subject of sex is of constant but rarely particularly topical interest." 40

Second, the requirement of judicial determination of the character of the expression recognizes that "[b] ecause the censor's business is to censor, there inheres the danger that he may well be less responsive than a court-part of an independent branch of government- to the constitutionally protected interests in free expression." 41 Yet a school administrator may well be even less responsive than a censor to constitutional considerations. Neither training nor experience prepares the administrator to apply complex constitutional standards to cases demanding a careful sifting of issues and weighing of facts. Further, he may have a greater interest in suppression than other censors. Unlike, for example, a movie censor who can afford to risk exhibiting a movie he thinks obscene, a school administrator faces the risk that a proposed speech will lead to violence or other forms of campus disruption. And should such violence or disruption occur, the institution's trustees, the state legislature, and the public are likely to hold him responsible. The result is administrative decisionmaking inevitably biased toward suppressing controversial speech. ${ }^{42}$

39 Shuttlesworth v. City of Birmingham, 394 U.S. 147, 163 (1969) (Harlan, J., concurring).

40 Carroll v. President \& Comm'rs of Princess Anne, 393 U.S. 175, 182 (1968) (quoting A Quantity of Copies of Books v. Kansas, 378 U.S. 205, 224 (1964) (Harlan, J., dissenting)).

41380 U.S. at $57-58$.

42 Attitudes of university and college administrators toward the presence of controversial speakers are described in $E$. WIIIAMSON \& J. COWAN, THE AMERICAN STUDENT's FREEDOM OF EXPRESSION (1966), a study carried out in 1964 under the auspices of the National Association of Student Personnel Administrators. Surveying all areas of the country, the study is based upon data obtained from 849 colleges and universities. Administrators at these institutions were asked to respond to a question distinguishing speakers who had spoken or would have been permitted to speak on campus from those which "might be considered so "controversial" that the administration would strongly question the advisability of their appearance." Id. 66. The administration of $94 \%$ of the institutions surveyed would have allowed Earl Warren to speak, and $80 \%$ would have found Martin Luther King acceptable. But only slightly more than half would have welcomed George Wallace or James Hoffa (55\% 
The Stacy rules fail to satisfy the Freedman requirements. ${ }^{43}$ First, the three-judge court in Stacy set no time limits for rendering a judicial determination. Although a court might voluntarily impose upon itself a four-day limit ${ }^{44}$ for reviewing and deciding a speaker ban case arising under the Stacy rules, this time schedule was not observed by the district court in Molpus. ${ }^{45}$ Second, despite the Court's command in Freedman that the censor's determinations have no effect of finality, the failure of the Stacy rules to compel a judicial determination within a specified time inevitably tends to make final the determinations of the school administrator and the campus review committee. Reversal of even clearly erroneous determinations depends upon the willingness of those aggrieved to undertake costly and time-consuming litigation, ${ }^{46}$ and both speaker and audience are precluded from exercising their first amendment rights pending the outcome of the litigation.

and $51 \%$ respectively). And less than one third would have welcomed Malcolm $X$ or George Iincoln Rockwell ( $30 \%$ and $21 \%$ respectively). In fact, even at the large public and nonsectarian universities - the most permissive institutions-only $41 \%$ would have openly accepted all of the 17 speakers listed on the questionnaire. Id. 72 . See also note 47 infra.

43 The rules fail to provide any procedural guidelines for the hearings before the campus review committee or to indicate whether any weight is to be given the committee's determinations. The district court in Molpus overcame these difficulties by granting a hearing de novo, a proper procedure in light of Freedman and Speiser v. Randall, 357 U.S. 513 (1958).

44 Rule (3) requires that applications be submitted 10 days before the date of the proposed speaking engagement, and that the head of the institution act within 4 days. Rule (5) requires that the campus review committee conduct a hearing within 2 days of the filing of an appeal from the determination of the head of the institution, leaving 4 days for judicial review and determination. $306 \mathrm{~F}$. Supp. at $979-80$.

45 The plaintiffs presented their request to the university on March 4 , with a speaking engagement scheduled for March 18. The complaint was filed in the district court on March 9, a hearing was held on March 14, counsel presented oral arguments on March 25, and the date of decision was March 31. 311 F. Supp. at 241-43.

46 The Stacy rules place the burden of seeking a hearing before the campus review committee upon the sponsoring organization aggrieved by a decision of the administrator. $306 \mathrm{~F}$. Supp. at 980 . Further, the committee's determinations "shall be final," unless judicial review is sought" by a "sponsoring organization aggrieved by [its] action." Id. Although the reviewing court may conduct a hearing de novo to determine the character of the proposed speech, note 43 supra, this procedure fails to overcome the effect of finality given the administrative determinations. The Freedman requirement of a timely judicial determination rests upon the Court's belief that in the absence of such a requirement, an administrative determination infringing first amendment rights might easily go unchallenged simply because of a lack of interest in litigation on the part of the parties affected.

[I]t may prove too burdensome to seek review of the censor's determination. Particularly in the case of motion pictures, it may take very little to deter exhibition in a given locality. The exhibitor's stake in any one picture may be insufficient to warrant a protracted and onerous course of litigation. The distributor, on the other hand, may be equally unwilling to accept the burdens and delays of litigation....

380 U.S. at 59 . Similarly, because delay in presentation may deprive a proposed speech of any value, the sponsoring group will often not be strongly motivated to secure judicial review of a denied request. Further, the sponsoring group would have to bear the cost of attorneys' fees. For example, the plaintiffs in Stacy requested that the university be required to pay $\$ 18,280$ in fees. Although the court denied the request because it was not made within a reasonable time after the entry of judgment, it indicated that such requests would generally be denied. Stacy $v$. Williams, 50 F.R.D. 52, 54-55 (N.D. Miss. 1970) (3-judge court). 


\section{CONCLUSION}

Banning controversial individuals from the campus may strike administrators as an effective means for insuring tranquility and avoiding public criticism, ${ }^{47}$ but "[f] ear of serious injury cannot alone justify suppression of free speech and assembly." 48 Controversial speech should be met not with suppression but with reasoned rebuttal, for truth can emerge only through the clash of ideas. ${ }^{49}$ Although school administrators are necessarily vested with discretionary power to set reasonable regulations of time and place for the presentation of speakers, ${ }^{50}$ prohibition of a proposed speech should require a judicial determination that the speech presents a clear and present danger to the institution's orderly operation. Only a tribunal whose members are insulated from the pressures of campus administration can adequately balance the right to speak against the need to maintain order. ${ }^{51}$

47 In 1964, 32\% of campus administrators surveyed in a study done for the National Association of Student Personnel Administrators indicated that considerable criticism had resulted from the appearance or from the proposed or actual invitation of certain speakers. E. WIILIAMSON \& J. CowAN, supra note 42, at 79. The major source of criticism was identified as off-campus conservative groups such as the John Birch Society. Id. Asked to identify speakers whose invitation to speak or actual appearance had caused considerable criticism, campus administrators listed such names as the following: Presidents Kennedy and Johnson, Justice William Douglas, Roy. Wilkins, Eleanor Roosevelt, Nelson Rockefeller, Strom Thurmond, Eunice Shriver, Edward Kennedy, and Justice Thurgood Marshall. Id. 79-80.

48 Whitney v. California, 274 U.S. 357, 376 (1927) (Brandeis, J., concurring). 49 Id. at 377 .

50 See Stacy v. Williams, 306 F. Supp. 963, 973 (N.D. Miss. 1969) (3-judge court); Wright, supra note 30 , at 1043 .

51 See Monaghan, supra note 32, at 522-24. 